\title{
Azoospermia and Severe Oligozoospermia in Indonesian Men Following Injections with Testosterone Enanthate or 19-Nortestosterone Plus Proges- togen
}

\author{
Nukman'Moeloek
}

\begin{abstract}
Abstrak
Tujuan penelitian ini adalah untuk mengetahui pengaruh Testosteron enantat (TE) atau 19-Nortestosteron heksiloksi fenil - propionat (19-NT) ditambah Depot medroksi progesteron asetat (DMPA) terhadap produksi sperma pada pria Indonesia sehat. Penelitian terdiri dari 2 fase yaitu fase kontrol dan fase penekanan. Empat puluh relawan sehat disuntik $200 \mathrm{mg}$ TE atau 19-NT tiap minggu selama 7 minggu, dilanjutkan dengan penyuntikan tiap 3 minggu hingga minggu ke-24. Pada kedua kelompok tersebut disuntik 250 mg DMPA pada minggu ke-0, 6, 12 dan 18. Hasil menunjukkan bahwa tidak terdapat perubahan volume semen, tetapi konsentrasi sperma, motilitas dan jumlah sperma dengan morfologi normal menurun. Tiga dari 40 pria tersebut tidak dapat melanjutkan penelitian ini karena gagal datang pada waktu yang ditetapkan (2 orang) dan karena alasan medik (1 orang), tetapi 2 orang dari mereka telah mencapai azoospermia dan 1 orang lagi konsentrasi spermanya telah mencapai $0,2 \times 10^{6} / \mathrm{mL}$. Tigapuluh tiga dari 37 pria $(89,2 \%)$ mencapai azoospermia dalam 21 minggu, dengan perincian 17 dari 18 pria (94,4\%) dari kelompok TE dan 16 dari 19 pria $(84,2 \%)$ dari kelompok 19-NT. Pencapaian oligozoospermia berat (konsentrasi sperma < 5 juta/mL) adalah 37 dari 37 pria (100\%) dalam waktu 15 minggu. Kedua perlakuan juga efektif untuk menekan motilitas sperma dan jumlah sperma dengan morfologi normal. Kesimpulan : Azoospermia dan oligozoospermia berat yang dicapai pria Indonesia yang disuntik TE atau 19-NT ditambah DMPA lebih besar dibandingkan pria Kaukasia.
\end{abstract}

\begin{abstract}
The objective of this study is to ascertain the effects of Testosterone enanthate (TE) or 19 - Nortestosterone hexyloxy phenyl-propionate (19-NT) plus Depot medroxyprogesterone acetate (DMPA) on the semen production in healthy Indonesian men. The prospective study consisted of 2 phases i.e. a control phase and treatment phase. Forty normal healthy male volunteers received seven weekly injections of TE or 19-NT, $200 \mathrm{mg} I M$, followed by injection every 3 weeks to week 24. In both groups $250 \mathrm{mg}$ DMPA was injected IM at 0, 6, 12, and 18 weeks. The results showed that there was no reduction in semen volume, but there was a reduction in sperm concentration, motility and the number of sperm with normal morphology in both groups. The three of 40 men discontinued injections for failure to atrend at scheduled time (2) and for medical reasons (1), but had achieved azoospermia (2) and the third man achieved sperm concentration of $0.2 \times 10^{6} / \mathrm{mL}$. Thirty three of 37 men (89.2\%) achieved azoospermia within 21 weeks, of these 17 of $18 \mathrm{men}(94.4 \%)$ from the TE group, and 16 of 19 (84.2\%) from the 19-NT group. The achievement of severe oligozoospermia (sperm concentration < 5 million/mL) was 37 of 37 men (100\%) within 15 weeks, of these 18 of 18 men (100\%) within 12 weeks from the TE group and 19 of 19 men (100\%) within 15 weeks from the 19-NT group. The two treatments were also effective in suppressing sperm motility, and normal morphology count. Conclusions: The rates of azoospermia and severe oligozoospermia in Indonesian men following injections of TE or 19-NT plus DMPA are higher compared to the Caucasian men (non Indonesian).
\end{abstract}

Keywords : Androgen, sperm analysis.

\section{INTRODUCTION}

Men are the forgotten $50 \%$ of family planning. The male role in family planning is often misunderstood, and clinical services focus almost exclusively on

Department of Biology, Faculty of Medicine, University of Indonesia, Jakarta, Indonesia women. There have been no improvements in male methods of family planning since the 19 th century. ${ }^{1}$ One of the reasons for the low participation of men in the family planning program is due to the restricted option of male contraceptives made available. ${ }^{2}$

The availability of various methods of contraception makes it possible for a person to use any method desired, so we may say that the more methods there are available, the more likely a person will use a contraceptive. ${ }^{3}$ 
Many researches have been conducted to find contraceptive agents that are both effective and safe. However, the development of methods to control male fertility is more complex than for women because the male can produce millions of sperm every day, while a woman releases only one ovum each month. In addition, a pill or injection for the male should not give rise to any serious side effects of sexual activity. ${ }^{4}$

Contraceptive preparations that have already been widely investigated are various combinations of androgen and progestogen. ${ }^{5-14}$ Specific combinations of androgen and progestogen that have been investigated are Testosterone Enanthate (TE) together with Depot Medroxyprogesterone Acetate (DMPA), and 19 - Nortestosterone hexyloxy-phenyl-proprionate (19NT) together with DMPA. 2,5-7,12 Although neither of these combinations has as yet been able to produce a $100 \%$ consistent azoospermia, an effective male contraceptive need not necessarily reach azoospermia, and may be effective simply by producing a condition where the ejaculate is infertile. Other semen analysis parameters such as motility or morphology of sperm are often much more important than the sperm concentration itself.

The purpose of this study is to ascertain the quantity and the quality of semen production i.e. sperma concentration mortility and morphology of men treated with Testosterone Enanthate (TE) or 19-Nortestosterone-hexyloxy-phenyl propionate plus DMPA.

\section{METHODS}

This study has been approved by the Research Ethics Commission, Faculty of Medicine, University of Indonesia and the Dean of Faculty of Medicine, University of Indonesia. All subjects gave a written informed consent to participate.
This study is divided into 2 phases, i.e. : control phase ( 1 month before treatment) and treatment phase (6 months).

In the control phase prior to treatment, 40 healthy Indonesian men between 21 and 45 years of age who had no active or chronic cardiac, hepatic, renal, or prostatic disease were recruited. Twenty men of this study were a part of a WHO multicentre trial on the efficacy of Testosterone Enanthate or 19-Nortestosterone hexyloxy-phenyl-propionate plus DMPA. ${ }^{5}$ A complete medical history was recorded, and a physical examination was performed on each volunteer. In addition, venous blood $(10 \mathrm{~mL})$ was taken for routine haematological examination and blood chemistry. Two semen samples were taken 2 weeks apart for analysis.

In the treatment phase, the volunteers were divided into 2 groups randomly, i.e. those receiving TE or 19-NT. In this phase, TE $200 \mathrm{mg}$ or $19-\mathrm{NT} 200 \mathrm{mg}$ were injected intramuscularly each week starting at week zero up to the sixth week. This treatment was then continued every 3 weeks after the sixth week up to the twenty-fourth week. DMPA $250 \mathrm{mg}$ was also injected intramuscularly at week zero, and continued every 6 weeks up to the 18 th. Semen analyses were made once every three weeks. Semen analyses were conducted based on WHO method. ${ }^{15}$

Baseline values were computed as the mean of the two before treatment values. A two-way analysis of variance (ANOVA) was used for statistical analysis.

\section{RESULTS}

This study was conducted from November 1988 to January 1991, at the Department of Biology, Faculty of Medicine, University of Indonesia, Jakarta.

A total of 40 men were recruited to the study. The baseline physical characteristics are shown in Table 1.

Table 1. The baseline physical characteristics of subjects

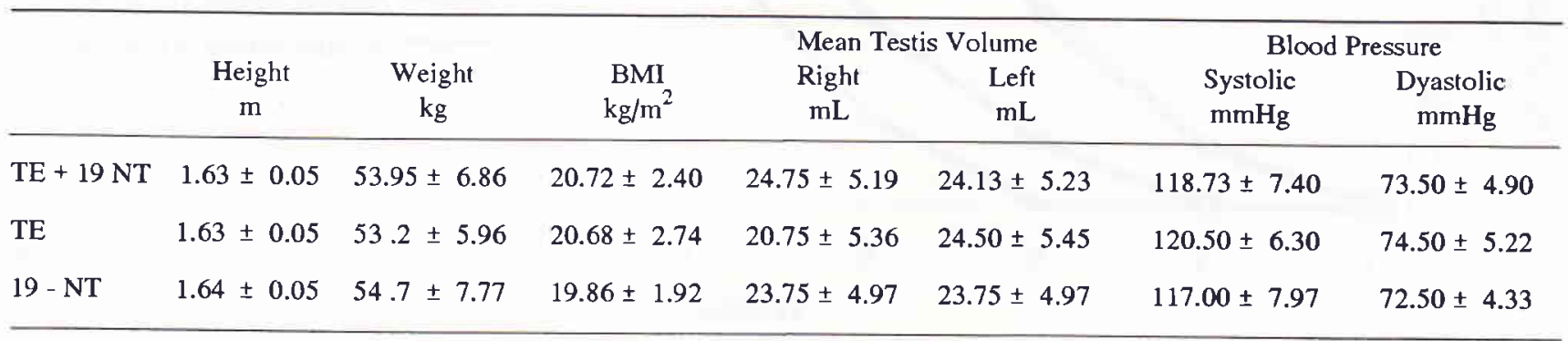

BMI : Body Mass Index

Values are mean $\pm S D$ 
Table 2. The mean results of semen analyses from 37 men before and during injections of TE and 19 NT plus DMPA

\begin{tabular}{ccccc}
\hline Weeks & $\begin{array}{c}\text { Volume } \\
\mathrm{ml}\end{array}$ & $\begin{array}{c}\text { Concentration* } \\
\times 10^{*} / \mathrm{mL}\end{array}$ & $\begin{array}{c}\text { Motility } \\
\text { \% motil }\end{array}$ & $\begin{array}{c}\text { Morphology } \\
\text { \% }\end{array}$ \\
\hline 0 & $2.58 \pm 0.79$ & $72.68 \pm 45.84$ & $65.35 \pm 9.29$ & $82.10 \pm 4.85$ \\
3 & $2.49 \pm 1.13$ & $43.48 \pm 36.95$ & $53.53 \pm 22.15$ & $76.85 \pm 13.04$ \\
6 & $2.49 \pm 1.15$ & $13.51 \pm 15.82$ & $31.50 \pm 23.33$ & $61.35 \pm 28.93$ \\
9 & $2.72 \pm 1.25$ & $2.49 \pm 5.96$ & $15.15 \pm 20.55$ & $34.45 \pm 34.97$ \\
12 & $3.06 \pm 1.08$ & $0.73 \pm 2.50$ & $9.42 \pm 18.47$ & $16.32 \pm 26.62$ \\
15 & $3.04 \pm 1.17$ & $0.17 \pm 0.45$ & $6.92 \pm 17.64$ & $5.51 \pm 12.20$ \\
18 & $2.78 \pm 1.27$ & $0.11 \pm 0.28$ & $2.35 \pm 8.80$ & $4.68 \pm 13.93$ \\
21 & $2.89 \pm 1.52$ & $0.14 \pm 0.44$ & $3.14 \pm 11.20$ & $5.11 \pm 14.98$ \\
24 & $3.13 \pm 1.48$ & $0.21 \pm 0.82$ & $2.35 \pm 6.92$ & $4.14 \pm 14.55$ \\
\hline
\end{tabular}

Values are mean $\pm \mathrm{SD}$

* $P<0.05$

A total of 37 of the 40 men completed the treatment phase. Of these, 33 men ( $89.2 \%)$ achieved two or more consistent azoospermic samples.

The mean results of semen analysis from the 37 men before and during treatment of TE and 19-NT plus DMPA are shown in Table 2.

\section{Semen volume}

The results of semen volume measurements showed that there was no significant difference between before and during treatment of TE or 19-NT plus DMPA ( $P$ $>0.05$ ) (see Table 2).

\section{Sperm concentration}

The statistical analyses showed that there were significant differences in sperm concentration between before and during the period of TE and 19-NT plus DMPA treatment $(P<0.05)$ (Table 2$)$. The rate and degree of suppression of sperm concentration were similar in the group of TE and 19-NT $(P>0.05)$. Cumulative rates of suppression to azoospermia and severe oligozoospermia $\left(<5 \times 10^{6} / \mathrm{mL}\right)$ by the time since the first injection of Testosterone Enanthate and 19-Nortestosterone plus DMPA, is shown in Figure 1.

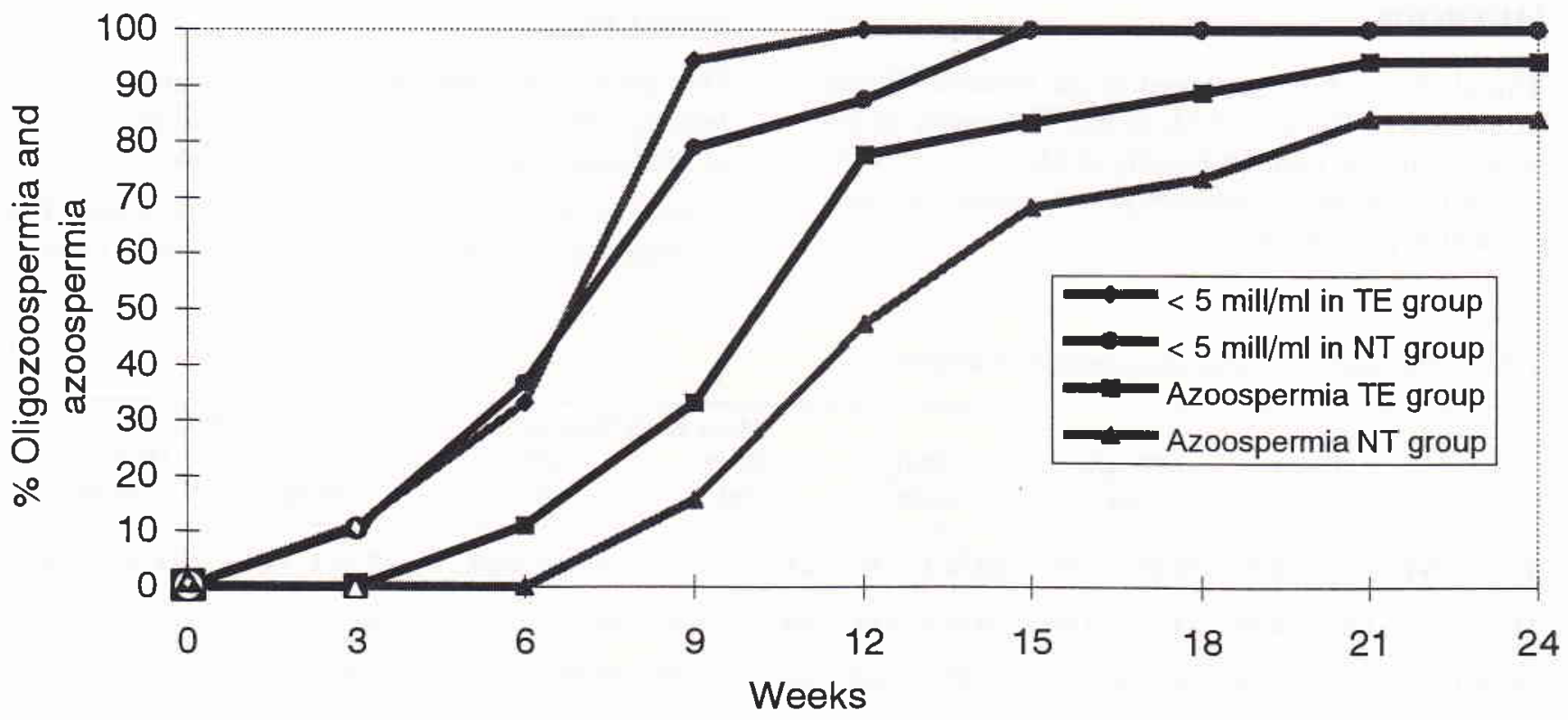

Figure 1. Cumulative rates of suppresion to severe oligozoospermia $\left(<5 \times 10^{6} / \mathrm{mL}\right)$ and azoospermia by the time since the first injection of TE or 19-NT plus DMPA 


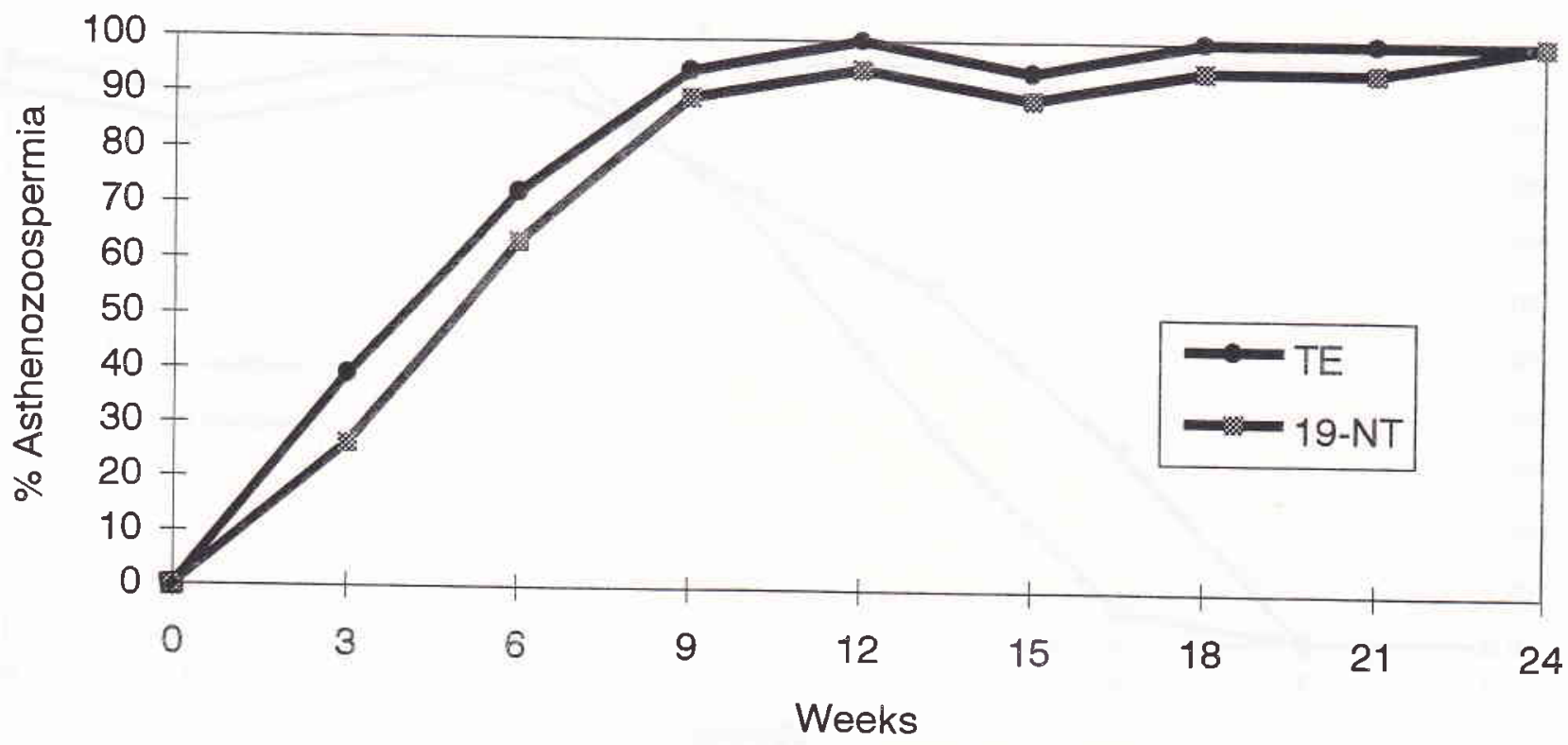

Figure 2. Cumulative rates of asthenozoospermia (sperm motility < 50\%) by the time since the first injection of TE or 19-NT plus DMPA

Thirty three of the 37 men ( $89.2 \%)$ achieved azoospermia within 21 weeks. Of these 17 of 18 men $(94.4 \%)$ and 16 of 19 men (84.2\%) from TE and 19-NT group respectively achieved azoospermia. The achievement of consistent severe oligozoospermia (sperm concentration $<5$ million $/ \mathrm{mL}$ ) was 37 of the 37 men $(100 \%)$ within 15 weeks, consisting of 18 of 18 men (100\%) within 12 weeks from TE, and 19 of 19 men (100\%) within 15 weeks from 19-NT group respectively.

\section{Sperm motility}

The sperm motility showed that there were significant differences between before and during treatment of TE and $19-\mathrm{NT}$ plus DMPA $(P<0.05)$ (Table 2$)$. There were no significant differences in the suppression of sperm motility between the TE and 19-NT group $(P>$ 0.05). Cumulative rates of asthenozoospermia (sperm motility $<50 \%$ ) by the time since the first injection of Testosterone Enanthate and 19-Nortestosterone plus DMPA, is shown in Figure 2.

\section{Sperm morphology}

The study on the number of sperm with normal morphology showed that there were significant differences between before and during treatment of TE and 19-NT plus DMPA $(P<0.05)$ (Table 2$)$. However there was no significant difference in the suppression of the number of sperm with normal morphology between the groups of TE and 19-NT $(P>0.05)$. Cumulative rates of teratozoospermia (normal sperm morphology
$<50 \%$ ) by the time since the first injection of TE and 19-NT plus DMPA, is shown in Figure 3.

Three of the $\mathbf{4 0}$ men discontinued injections for failing to attend at the scheduled times (2) and for medical reasons (1). Of those men, two had achieved azoospermia at weeks 9 and 12 with TE plus DMPA, and one man achieved a very low sperm concentration of 0.2 $\mathrm{x} 10^{6} \mathrm{~mL}$, with sperm motility of $8 \%$, and normal sperm morphology of $0 \%$ at week 9 with $19-\mathrm{NT}$ plus DMPA.

All of the clinical chemistry and hematology findings were in the normal range during the treatment phase (data not shown), except that $1 \mathrm{man}$ had an increase in liver function test (the one subject who discontinued).

\section{DISCUSSION}

Out of the 37 men who finished the study 33 men $(89.2 \%)$ achieved azoospermia. In the TE group 17 men out of 18 men $(94.4 \%)$ achieved azoospermia since week 21 , and the remaining $1 \mathrm{man}$ had not achieved azoospermia, but his sperm concentration was suppresed to $0.80 \mathrm{million} / \mathrm{mL}$. In the $19-\mathrm{NT}$ group there were 16 men out of 19 men $(84.21 \%)$ who achieved azoospermia. In this group there were 3 men who had not yet achieved azoospermia, i.e. 1 man with sperm concentration below $1 \mathrm{million} / \mathrm{mL}$, and 2 men with sperm concentrations below 5 million $/ \mathrm{mL}$ (1.50 mill./mL and $4.80 \mathrm{mill} . / \mathrm{mL})$. The achievement of azoospermia in this study is high enough. Moreover, when we observe the 3 men who did stop the study, 2 


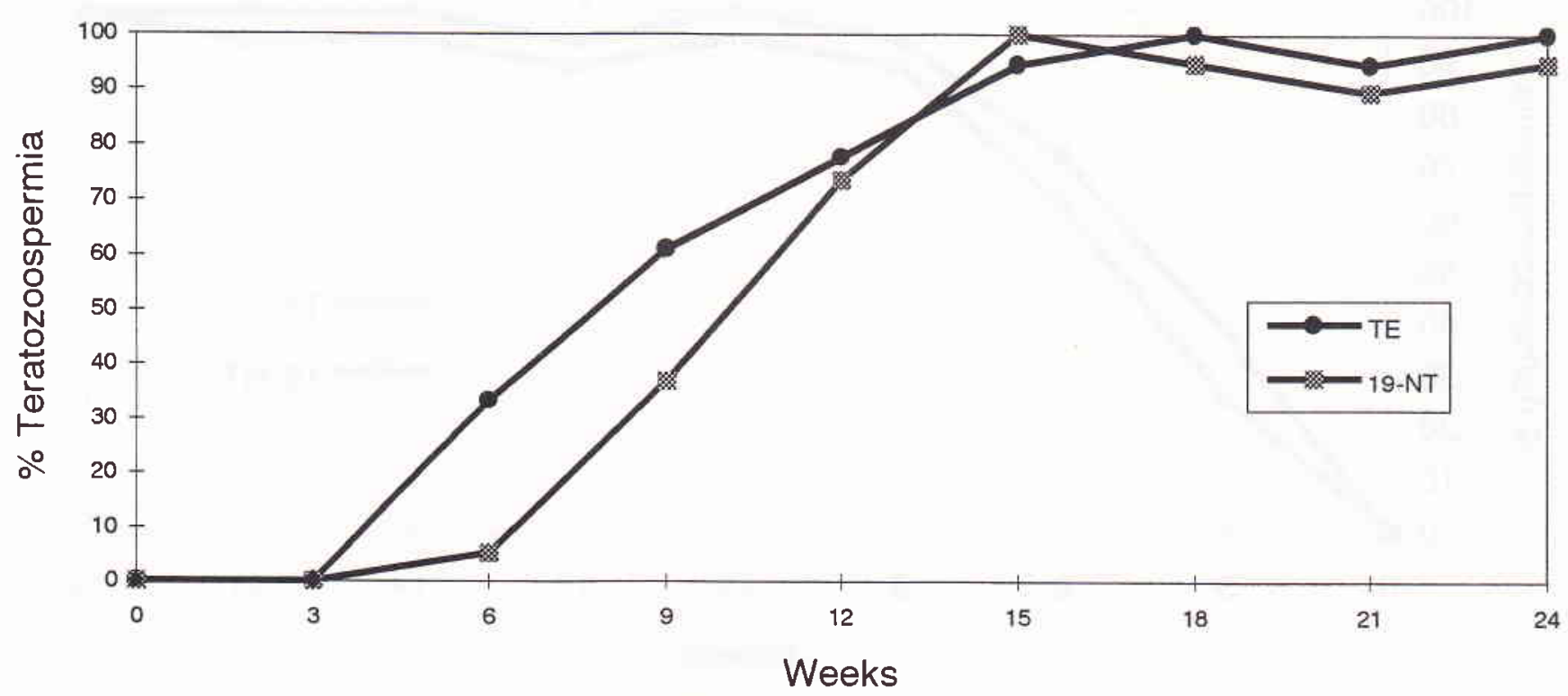

Figure 3. Cumulative rates of teratozoospermia (normal sperm morphology < 50\%) by the time since the first injection of TE or 19-NT plus DMPA

men (of the TE group) had achieved azoospermia and another one (of the 19-NT group) the sperm concentration had achieved less than 1 million/mL even though only treated for 9 weeks. WHO reported that Indonesian men treated with TE or 19-NT plus DMPA, $96.7 \%$ achieved azoospermia $(95.6 \%$ and $97.8 \%$ in TE and 19-NT group, respectively). ${ }^{5}$ Another study reported that every month injections of TE plus DMPA achieved higher rates of azoospermia in twenty Indonesian men. ${ }^{6}$ The differences may be due to different numbers of subjects. In the Caucasian men the achievement of azoospermia using TE plus DMPA and 19-NT plus DMPA was less than $70 \% .^{7-12}$ So the achievement of azoospermia in Indonesian men is higher compared to the Caucasian men. The differences in the achievement of azoospermia between the Indonesian and Caucasian men may be related to diffe-rences in genetic and environmental factors, including metabolism and nutrition.

In this study, there was no significant difference in the effects of TE plus DMPA compared to 19-NT plus DMPA on the sperm concentration. This means that both regimens have the same effect in the suppression of sperm concentration produced by the testes. The absence of significant difference in the lowering of sperm concentration between TE and 19-NT groups probably due to the strong effect of DMPA in the suppression of spermatogenesis. Furthermore, the progestogen and androgen have a synergetic effect on the suppression of spermatogenesis. ${ }^{16,17}$ The suppression of FSH, LH, and testosterone which causes suppression of spermatogenesis has been reported by several authors using treatment of TE plus DMPA ${ }^{5,7,8,13,14}$ as well as 19-NT plus DMPA. ${ }^{5,12}$

It should be supposed that there is no need to achieve azoospermia for a contraceptive. The number of fertile spermatozoa in the ejaculate need only to be reduced to a sufficient degree to induce consistent infertility. It has been proven that men treated with TE plus DMPA, and whose sperm concentration was $<5$ million $/ \mathrm{mL}$, the sperm function tests were poor. ${ }^{18}$ So the sperm function test of the residual sperm during and after treatment should be investigated in further study. In this study (Figure 1) at week 15, 37 of 37 men (100\%) had achieved sperm concentration of $<5 \mathrm{million} / \mathrm{mL}$. So in this case, on week 15 both TE plus DMPA as well as 19-NT plus DMPA possibly are effective as a male contraceptive. If we investigate further, it can be seen that in the TE plus DMPA group $100 \%(18 / 18)$ had achieved sperm concentration of $<5$ million/mL (severe oligozoospermia) at week 12, compared to the 19-NT group in which $100 \%$ (19/19) achieved sperm concentration of $<5$ million/ $\mathrm{mL}$ at week 15 (Figure 1). So in this matter, TE plus DMPA may possibly be a faster contraceptive (week 12) than 19-NT plus DMPA (week 15). In the Caucasian men, using TE or 19-NT plus DMPA never achieved $100 \%$ severe oligozoospermia $(<5 \mathrm{million} / \mathrm{ml})$ consistently after 12 weeks of injections. ${ }^{7,8,12-14}$ 
Sperm motility also decreased by the time of administration of TE plus DMPA and 19-NT plus DMPA. Another point, the decreasing sperm motility was greater in the TE plus DMPA than 19-NT plus DMPA group. This was caused by the greater change in morphology in the TE plus DMPA compared to the 19-NT plus DMPA group, so that the sperm tail as the main factor for the sperm motility was influenced. The decrease in sperm motility is also reported by others who did study on TE plus DMPA, ${ }^{7,8,14}$ as well as 19-NT plus DMPA. ${ }^{12}$

Figure 2 shows that the TE plus DMPA group achieves $100 \%$ asthenozoospermia in week 12 , but the 19-NT plus DMPA group just achieves $100 \%$ asthenozoospermia in week 24. This also shows that the TE plus DMPA may possibly be faster as a male contraceptive compared to 19-NT plus DMPA. This might be due to the androgenic effect of TE that is supposed to be greater than 19-NT, hence the suppression of gonadotrophin hormone by TE should also be greater than 19-NT, which causes the decrease in intratesticular testosterone, resulting in the faster decrease in sperm motility.

The number of sperm with normal morphology decreased after administration of TE and 19-NT plus DMPA (Table 2). The decrease was greater in the TE plus DMPA compared to the 19-NT plus DMPA group. It is possible that TE is more androgenic than 19-NT, so that TE could more suppress intratesticular testosterone than 19-NT. It is already proven that spermatogenesis (pachytene) needs testosterone. ${ }^{19}$ Testicular biopsy of men treated with TE plus DMPA showed arrestation of spermatogenesis and germ cell depletion. ${ }^{8}$ Knuth et al ${ }^{11}$ has proven that administration of 19-NT plus DMPA decreased the number of sperm with normal morphology in the semen of the experimented volunteers.

Figure 3 shows that the TE and 19-NT plus DMPA administration can achieve $100 \%$ teratozoospermia by week 18 and 15 respectively. The achieving of $100 \%$ teratozoospermia was faster than azoospermia, suggesting the possibility that both combinations can be used before week 21 as a male contraceptive.

Considering the achievement of all subjects to suppress sperm concentration to $<5 \mathrm{million} / \mathrm{mL}$, with a decrease in sperm motility and the number of sperm with normal morphology in the TE plus DMPA group by week 12, as well as in the 19-NT plus DMPA group on week 15 , both regimens have good prospect to be used as a male contraceptive .

\section{CONCLUSION}

It can be concluded that severe oligozoospermia occurred in 100\% of Indonesian men within 12 and 15 weeks after the first injection with Testosterone Enanthate (TE) or 19-Nortestosterone hexyloxy-phenylpropionate (19-NT) plus DMPA respectively. Oligozoospermia was accompanied by a decrease in sperm motility and the number of sperm with normal morphology, to below the normal limit value. Within 21 weeks, the achievement of azoospermia was $94.4 \%$ in the TE and $84.26 \%$ in the $19-\mathrm{NT}$ group respectively.

\section{Acknowledgments}

I thank Dr. Joedo Prihartono, MPH. and Ir. Budi Susetyo, MS. for their assistance with statistical analyses. I also thank Mr. Sutardjo and Mr. Yuliadi, technical assistants, for performing the semen analyses. This work was partly supported by the Special Programme of Research, Development and Research training in Human Reproduction, World Health Organization, Geneva, Switzerland, and the United $\mathrm{Na}$ tions Populations Fund

\section{REFERENCES}

1. Potts DM. Male contraception in family planning programs. In : Zatuchni G, Goldsmith A, Spieler JM, Sciarra JJ, editors. Male contraception, advances and future prospects. Philadelphia: Harper \& Row, 1986:2-6.

2. Moeloek N. Kontrasepsi pria : masa kini dan masa akan datang. Medika 1990;2:151-9.

3. Affandi B. Clinical, pharmacological and epidemiological studies on a levonorgestrel implant contraceptive [dissertation]. Jakarta: Universitas Indonesia, 1987.

4. Tadjudin MK. Cara keluarga berencana hormonal pada pria. In: Prosiding Kongres-Nasional I. Perkumpulan Endokrinologi Indonesia; 1986 Nov 22-25; Jakarta. Jakarta: Balai Penerbit FKUI, 1986:23.

5. WHO. Task force on methods for the regulation of male fertility. Comparison of two androgens plus depotmedroxyprogesterone acetate for suppression to azoospermia in Indonesian men. Fertil Steril, 1993;60:1062-8.

6. Pangkahila W. Reversible azoospermia induced by an androgen-progesterone regimen in Indonesian men. Int $\mathrm{J}$ Androl 1991;14:248-56.

7. Alvarez-Sanchez, Faundes A, Brache V, Leon P. Attainment and maintenance of azoospermia with combined monthly injection of depot Medroxyprogesterone Acetate and Testosterone Enanthate. Contraception 1977;15:635-47.

8. Brenner PF, Mishell DR, Hano R, Gunnarson PO, Nieschlag E. Study of depot Medroxyprogesterone Acetate and Testosterone Enanthate as male contraceptive. Contraception 1977;15:679-91

9. Frick J. Bartsch G, Weiske WH. The Effect of monthly Depot Medroxyprogesterone Acetate and Testosterone on human spermatogenesis. I. Uniform dosage levels. Contraception 1977;15:649-59. 
10. Melo JF, Coutinho FM. Inhibition of spermatogenesis in men with monthly injections of Medroxyprogesterone Acetate and Testosterone Enanthate. Contraception 1977;15:627-34.

11. Frick J, Danner C, Kunit G, Joos H, Kohle R. Spermatogenesis in men treated combined with testosterone enanthate. Int J Androl 1982;5:246-52.

12. Knuth UA, Yeung $\mathrm{CH}$, Nieschlag E. Combination of 19 -nortestosterone hexyloxyphenylpropionate (Anadur) and depot-medroxyprogesterone acetate (Clinovoir) for male contraception. Fertil Steril 1989;51:1011-8.

13. Frick J, Bartsch G, Weiske WH. The Effect of monthly depot Medroxyprogesterone Acetate and Testosterone on human spermatogenesis. II. High initial dose. Contraception 1977;15:669-77.

14. Hedman M, Gottlieb C, Svanborg K, Bygdeman M, Dela Tore B. Endocrine, seminal and periheral effect of depot
Medroxyprogesterone Acetate and Testosterone enanthate in man. Int $J$ Androl 1988;11:265-76.

15. WHO. Laboratory manual for the Examination of human semen and semen-cervical mucus interaction. Cambridge: Cambridge University Press, 1987.

16. Bain J. Androgen-progestin combinations : clinical trials. In: Cunningham R, Schill WB, Hafez ESE, editors. Regulation of male fertility. London: Martinus Nijhoff, 1980:85-92.

17. Henzl MR. Contraceptive hormones and their clinical use. In : Yen SSC, Jaffe RB editors. Reproductive Endocrinology. Philadelphia, Saunders, 1986:643.

18. Matsumoto AM. Is high dosage testosterone an effective male contraceptive agent. Fertil Steril 1988;50:324-8.

19. Steinberger E. Hormonal control of mammalian spermatogenesis. Physiol Reviews 1971;51:1-22. 